\title{
Appraisal of Continuous Use of Public Debt on the Nation's Growth and Development
}

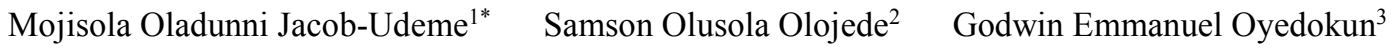 \\ 1.Administrative Department, Dominion University, Ibadan, Nigeria \\ 2.Bursary Department, University of Ibadan, Nigeria \\ 3.Professor, Department of Management \& Accounting, Faculty of Social \& Management Sciences, Lead City \\ University, Ibadan, Nigeria
}

\begin{abstract}
The paper examines the continuous use of public debt in Nigeria, the effect of growth and development on the nation. The nature of public debt was discussed before considering reasons most nations including Nigeria go for public debt. The Ricardo Theory of public debt was the theoretical framework for the paper. The relationship between public debt and national development was also explored. Based on that conclusion was reached.
\end{abstract}

Keywords: External debt; domestic debt; growth; development

DOI: $10.7176 / \mathrm{JRDM} / 78-03$

Publication date:August $31^{\text {st }} 2021$

\section{Introduction}

Macroeconomic challenges and poor human conditions facing the developing nations necessitated social and economic development plans, which have resulted in a fiscal deficit due to a low-income base and consequently, lead to public debts (John \& Muhammad, 2013). By implication, a high level of public debt outstanding means high debt servicing due to an increase in the budget deficit, financed by raising public borrowings thereby increasing the level of the nation's public debt. Public debt increase as experienced by many developing countries of the world had been come global concern, following the fall in oil prices, variation on exchange rate etc which has brought adverse effect to some developing nations of the world such as Nigeria.

The accumulation of such debt may not only entangle the nation in a debt trap but may also limit their sovereign fiscal options, which exposes the country to macroeconomic risks such as compressing the social and development spending. As a result, it would compromise the objectives of social and development plan for which the debt was raised (Fan, 2007). Debt or borrowings have been described as an important instrument of fiscal policy available to government to fund the development of a nation. Debt is employed in causing the settlement of expenditures that will ultimately increase productivity and improve the growth of the economy (Muhammad, Ruhaini, Nathan \& Arshad, 2017). Although, studies have ascertained a negative impact of public debt usually a particular level on the growth of most developing economies (Panizza \& Presbitero, 2013; Reinhart \& Rogoff, 2010). Budget deficits demonstrate that government expenditure is higher relative to its revenue, this gap has been identified to be filled with public debt (Mankiw, 2013). Public debt which includes both internal (domestic) and external debts is considered when the revenue realized by the governable is insufficient for its projected expenditures (Rahman, 2012).

In order to encourage growth, countries at early stages of development like Nigeria borrow to augment what they have because of dominance of small stocks of capital hence they are likely to have investment opportunities with rates of return higher than that of their counterparts in developed economies. This becomes effective as long as borrowed funds and some internally ploughed back funds ${ }^{1}$ are properly utilized for productive investment, and do not suffer from macroeconomic instability, policies that distort economic incentives, or sizable adverse shocks. Growth therefore is likely to increase and allow for timely debt repayments. When this cycle is maintained for a period of time growth will affect per capita income positively which is a prerequisite for poverty reduction (Amakom, 2003). These predictions are known to hold even in theories based on the more realistic assumption that countries may not be able to borrow freely because of the risk of debt denial.

\section{Conceptual Clarification}

2.1 Public Debt

Public debt has been described as one of the major indicators of the macroeconomic variables, which forms the image of countries in the international markets. Generally, it is one of the determinants of foreign direct investment flows. Prudent management of public debt increases economic growth and stability via resources mobilization with low borrowing cost and limited financial risk exposure (Christabell, 2013). Public debt can also be described as the total debts of a country, which include debts of governments at all levels such as local, state and national governments, thereby showing how many public expenditures are financed through borrowing instead of taxation (Makau, 2008 cited in Christabel, 2013). Public debt is one of the approaches used in financing government projects, even though the approach is not the only way the government can finance its 
operations as she can also create money to monetize its debts, and by creating money to finance government operations, the need to pay interest may be removed (Martin, 2009).

Public debt is classified into domestic debt and external debt. Chowdhury (2001), opined that nations at their early stage of development, suffer from inadequate capital stocks and limited investment opportunities. Therefore, a reasonable level of external debt is required to complement the domestic resources to promote growth via capital accumulation and productivity growth. Thus, government external borrowing based on productive investment leads to macroeconomic stability. Burnside (2000) posited that external debt brings about the capital inflow of funds in the economy and as well as has a positive impact on the national savings, investments, and growth rates. Government of all levels can default their debt, and in order to avoid default on public debt supranational like the International Monetary Fund are invested with great power by the international community to make sure that nations will not default and also to control numerous financial issues if there is any signal to show that the nation want to default.

In the other hands, if state or local government default their debts the country would pay the debt. If budget deficit of any government rises, it will lead to increase on public debt. Public debt can be classified into different types such as long-term debt when the debt is expected to last for a longer period of time and short-term debt if debt is designed to last for one or two years only. Domestic Debt is defined as debt that government borrowed within the country, it involves the same currency. Therefore all the amount of money that government owes internally such as Treasury Bills, Treasury Certificates, Federal Government Development Stock, Ways and Means Advances and Treasury Bonds is regard as domestic debt (Babu, Symon, Aquilars \& Mose, 2015). However, Cecchetti, Moharty, and Zampoli (2010) contended that the lack of changes in fiscal policy, debt will continue to accrue as government expenditure has always been on the increase despite declining revenue.

They further mentioned that as the risk embedded in the issuance of bonds continue to increase and the increasing population may continuously occasion the dynamism in public debt. Hence, the current debt crisis has revivified the policy and academic discussion concerning the effects of public debt on economic growth. Although the upswing in academic researchers conducted on this focus are bereft of adequate empirical evidence from countries of the world on the connection between public debt and economic activity. Obi (2014), argued that most theoretical literature on the nexus between external debt stock and growth-focused largely on the adverse effects of debt overhang. Debt overhang according to Krugman (1998), is defined as a condition by which the expected repayment on external debt falls short of the contractual value of debt. If the level of a nation's debt is expected to exceed the country's ability to repay with some probability in the future, expected debt service is likely to be an increasing function of the output level of the county. The returns from investing in the domestic economy may effectively be taxed away by existing foreign creditors and investment by foreign and domestic investors, and hence, economic growth is discouraged.

\subsection{Public Debt and National Development}

According to Matiti (2013), the importance of resources for government spending cannot be overemphasized. Most of the public revenue is mainly provided by tax revenue while government borrowings topically bridge the resource gap between the receipt and the expenditure. The government borrowing could either be from the domestic market or abroad. However, in a situation where the domestic markets are undeveloped, foreign sources provide the bulk of financing the resource gap. Matiti (2013), further upheld that the domestic debt could have severe effects on the economy if not adequately balanced with the levels of economic development anticipated in the economy. Hence, domestic debt servicing tend to absorb the greater part of government revenues that would ordinarily be channeled towards developmental projects to accelerate economic growth. This implies that the government is left with fewer resources to spend on development projects. In this view, however, domestic debt servicing is argued to have a more harmful effect on economic growth than the external debt stock due to its shrinking effects (Abbas \& Christensen, 2007).

In the words of Adepoju, Salau and Obayelu (2007), developing nations in Africa, Nigeria inclusive internally suffer from inadequate capital formation resulting from the "vicious circle of low-income, low savings, and low-productivity". This situation, therefore, technically requires financial and managerial support sourced externally to bridge the resource gap. External debt, however, acts as the major constraint to capital formation in Nigeria. The dynamics and the burden of external debt is an indication that its contribution is very insignificant to financing economic development projects in the economy. Although Nigeria is rich in both natural and human resources, the present day modern technology and development process still requires that foreign capital is needed to complement the capital requirements of the economy for development. It was in an attempt to complement the capital needs that necessitate Nigeria to embark on contracting jumbo foreign loans from 1978 with the aim to promote growth and development; and hence, improve the standard of living of the entire citizens of the country (Obi, 2014).

The role of public debts in promoting economic growth has overtime been studied by several scholars, but recently it has undergone a very notable revival probably fuelled by the substantial weakening of public finances 
in different economies, occasioned by the 2008 financial crisis (Alejandro \& Ileana, 2017). Several works exist on the dichotomy in favor of and against public borrowings as a way of driving the economy. Some of this literature include Ogiemudia and Ajao (2012), Sulaiman and Azeez (2012), Oke and Sulaiman (2012), etc. these scholars conceived foreign debt as a catalyst for economic growth, whereas others such as Ajayi and Oke (2012), Muritala (2012), Uma, Eboh and Obidike (2013), etc., upheld that foreign debt deters economic growth and development of nations. As the war becomes fierce between the scholars, the position of the third party is likened to those who abstain themselves from identifying with either of the school of thoughts, but conceived that public debt is bad; however, countries cannot avoid it. In light of this, public debt was described as a necessary evil. This implies that borrowing remains good until it reached the point in which it makes the economy worse off.

Meanwhile, the implication of domestic debt has been insignificantly considered especially in the literature due to the uncritical nature of its conditions. This connotes that prior to the advent of the Structural Adjustment Programme (SAP) in the 1980s, several African countries accorded an insignificant interest to the adverse effect caused by domestic debts to the economies of most of these countries especially Nigeria. This has caused numerous countries to resort to their central banks in their bid to amass resources necessary for debt servicing (Idris and Ahmad, 2017). Essien et al., (2016) asserted that this event has triggered numerous macroeconomic issues including liquidity challenge, increasing inflation rate, high monetary expansion, and limited loanable funds for private investment among others.

\section{Reasons for Public Debt}

Soludo (2003) cited in Attapattu and Padmasiri (2018), emphasized that most countries borrow for two broad macroeconomic reasons including to either finance higher investment or higher consumption and to circumvent hard budget constraint. These imply that countries borrow to boost economic growth and reduce poverty level in the economy. Accordingly, Soludo (2003), explained that the macroeconomic basis for which public debt is accumulated is geared towards achieving the goals of high investments, and consumption such as health and education or financing deficits in the transitory balance of payments as well as to outwit hard budget constraints. It is also accumulated to lower nominal interest rates abroad and lack of domestic long-term credit. On the other hand, the reason for debt accumulation by the government to financing budget deficits is mainly an attempt to complement the domestic savings to finance government projects and promote the nation's economic growth. In developing countries, where the advancement of the economies depends heavily on the borrowings, debt overhang is inevitable.

In the view of Tajudeen (2012) cited in Isaac and Rosa (2016), reasonable borrowing level by developing nations is likely to accelerate their economic growth. When the economic growth of the nations improved, the poverty situation in the economy will positively be affected. For growth to be encouraged, nations at early development stages, borrow to compliment the inadequate domestic capital stock and provide more investment opportunities with rates of return higher than that of their counterparts in the developed economies. Thus, if the borrowed funds and ploughed back funds are adequately utilized for productive investments, it results in macroeconomic stability of the economy. Therefore, growth is likely to increase and allow for timely debt repayments.

Arguably, scholars postulated that the less debt-burdened countries tend to have higher rates of growth than the higher debt-burdened nations. This is because the emerging countries and less developed countries accumulate more debt for the reason of promoting economic growth due to their inability to generate enough resources to bridge budget deficits gap and enhance economic growth. Governments prefer debt accumulation in financing budget deficits due to its anti-inflationary effects unlike imposing taxes or printing new money. Although taxes can be used by the government to finance the budget deficit, it however, tends to distort the structure of relative prices; and public debt, if it exceeds the carrying capacity of the economy, creates problems of international equity among nations (Akram, 2011). According to Kibui (1997), the fundamental factor that causes public debt to rise is over-reliance on external borrowings to augment capital formation in the nation's economy. If the interest payment is high, the deficit on the current account will also be high thereby resulting in the huge debt burden.

Isaac and Rosa (2016) also postulated that sub-national governments acquire debt mainly to financing public investment projects that complement the private investments to translate into improved economic growth, from which the contracted debt becomes sustainable and no risk for their finances. Nassir and Wani (2016), opined that a debt implies an obligation to pay money, deliver goods, or render service under an express or implied agreement. Hence, they described public debt as the total debts of the nation which include debts of national, state and local governments that revealed how much public spending is financed through borrowing instead of taxation 


\section{Theoretical framework}

4.1 Ricardo Theory of Public Debt

This theory of public debt was propounded by David Ricardo in 1819. In his Principles, Ricardo developed the theory of public debts by stating that the ordinary and extraordinary spending of government were mainly payments made to sustain unproductive laborers. Therefore, any saving from the government expenses would be included in the income if not to the capital of the contributors. Ricardo in a letter written to McCulloch in 1816 believed that public expenditure was wasteful venture undertaken by the state. Ricardo's theory of public debts was then, based on the fact that the primary burden to the community was derived from the wasteful nature of public expenditure itself rather than from the methods adopted to finance such expenditure (Precious, 2015). The theory postulated that financing public expenditure should be focused on drawing the funds from the liquid resources of the community.

This is because to focus on the economy, does not make any significant difference whether the funds were raised by loans or taxes. Accordingly, Ricardo argument about payments of interest on public debt deals with a transfer of wealth from one pocket to another within the society. Thus, when countries borrow, it is uncertain whether the loan would be used productively or unproductively. If the loan is used productively, it leads to growth, but it is used unproductively, it deters economic growth in the economy (Okoye, Modebe \& Evbuomwan, 2013). In conclusion, this theory is relevant to this study as it would help to determine whether actually, the government expenditures in Nigeria have over time been used productively or unproductively according to the theory.

\section{Conclusion and Recommendations}

Government should reduce external debt and the ones obtained should be strictly use for purposes intended to ensure positive effect. The reason is because domestic debt (DMD) has significant negative relationship with economic growth. Reduction in domestic borrowing and ensuring that the existing ones are applied for purposes intended to ensure positive effect and growth is crucial. With the evidence of negative causality running from both external and domestic debt stock to economic growth (RGDP), it is suggested that government should cut down in both borrowings to ensure economic stability and sustainable growth.

\section{References}

Abbas, S.M.A., \& Christesen, J. (2007). The role of domestic debt markets in economic growth: An empirical investigation for low-income countries and emerging markets. Working Paper 07/127. Washington, DC: International Monetary Fund.

Adepoju, A.A., Salau, A.S., \& Obayelu, A.E. (2007). The effects of external debt management on sustainable economic growth and development: lessons from Nigeria. Paper No. 2147, Munich Personal RePEC Archieve (MPRA), Munich.

Ajayi, L. B., \& Oke, M. O. (2012). Effect of external debt on economic growth and development of Nigeria. International Journal of Business and Social Science, 3(12), 18-29.

Akram, N., Padda, I., Khan, M., \& Husnain, I. (2011). Fiscal situation in Pakistan and its consequences for economic growth and poverty. American International Journal of Contemporary Research, 1(1), 94-111.

Attapattu, A. M. C. P., \& Padmasiri, H. M. N. (2018). Long run effect of public debt on economic growth in Sri Lanka. IOSR Journal of Business and Management (IOSR-JBM), 66-73.

Babu JO, Symon K, Aquilars MK, Mose G. (2015) Effect of domestic debt on economic growth in the east African community. American Journal of Research Communication, 3(9):73.

Burnside, C., \& Dollar, D. (2000). Aid, policies, and growth. American Economic Review, 847-68.

Chowdhury, A. R. (2001). External debt and growth in developing countries: A sensitivity and causal analysis. WIDER Discussion Paper No. 2001/95.

Christabell, M. (2013). The relationship between public debt and economic growth in Kenya. International Journal of Social Sciences and Project Planning Management, 1(1), 1-21.

Essien, S. E., Agboegbulem, N. T. L., Mba, M. K., \& Onumonu, O. G. (2016).An Empirical Analysis of the Macroeconomic Impact of Public Debt in Nigeria. CBN Journal of Applied Statistics. 7(1), 125-136.

Fan, E.X. (2007). Pakistan"s public debt: A brief overview, PRM policy note, series 1. Asian Development Bank, Islamabad

Idris, M. and Ahmad, T.S. (2017). The Productivity of Public Debt Borrowing and Economic Growth in SubSaharan Region: The Nigerian Context. International Journal of Economics, Commerce and Management. $5(6), 340-373$

Isaac, S., \& Rosa, G. (2016). Public debt, public investment and economic growth in Mexico. International Journal of Financial Studies, 4(6), 1-14.

John, P. A., \& Muhammad, A. Q. (2013). System dynamics model of debt accumulation in developing countries. African Journal of Economic and Management Studies, 4(3), 317-337 
Kibui, P. (1997). Impact of external debt on public investment and economic growth in Kenya (1970-2007). Unpublished MBA Project, University of Nairobi.

Matiti, C. (2013). The relationship between public debt and economic growth in Kenya. International Journal of Social Sciences and Project Planning Management, 1(1), 65-86.

Muhammad, D.A.B., Ruhaini, M., Nathan, S.B. \& Arshad, (2017).Real effects of government debt on sustainable economic growth in Malaysia. Journal of International Studies. 10(3), 161-172

Muritala, T. A. (2012). Empirical analysis on impact of external debt on economic growth in Nigeria. Acta Universitatis Danubius, 8(6), 1-13.

Nassir, U. H., \& Wani, H. K. (2016). An evaluation of relationship between public debt and economic growth: A study of Afghanistan. Munich Personal RePEc Archive, 75538, 1-19.

Obi, C. K. (2014). An estimation of the critical levels of external debt accumulation: The Nigerian experience. International Journal of Sustainable Development, 7(12), 73-82

Ogiemudia, A. O. \& Ajao (2012). Foreign debt management and the development of Nigeria economy. Review of Economic and Finance, Academic Research Centre of Canada

Oke, M. L., \& Sulaiman, L. A. (2012). External debt, economic growth and investment in Nigeria. European Journal of Business and Management, 4(11), 82-102.

Okoye, L. U., Modebe, N. J., Erin, O. A., \& Evbuomwan, G. O. (2013). Effect of external debt on economic growth: Evidence from Nigeria. Sustainable Economic Growth, Education Excellence, and Innovation Management through Vision 2020, 4046-4058

Panizza, U. \& Presbitero, A.F. (2013). Public Debt and Economic Growth in Advanced Economies: A Survey. Swiss Society of Economics and Statistics. 149(2), 175-204

Precious, L. N. (2015). Effects of public debt on economic growth in Swaziland. International Journal of Business and Commerce, 5(1), 1-24.

Rahman, N.H. (2012). How Federal Government's Debt Affect the Level of Economic Growth? International Journal of Trade, Economics and Finance. 3(4), 323-326.

Reinhart, C. M., \& Rogoff, K. S. (2010).Growth in a Time of Debt, American Economic Review. In Papers and Proceedings. 100(2), 1-9.

Sulaiman, L. A., \& Azeez, B. A. (2012). Effect of external debt on economic growth of Nigeria. Journal of Economics and Sustainable Development, 3(8), 71-83

Uma, K., Eboh, F., \& Obidike, P. (2013). Debt and debt service: Implications on Nigerian economic development. Asian Journal of Social Sciences and Humanities, 2(2), $42-54$. 